\title{
Mechanical, Hygric and Thermal Properties of Flue Gas Desulfurization Gypsum
}

\author{
P. Tesárek, J. Drchalová, J. Kolísko, P. Rovnaníková, R. Černý
}

The reference measurements of basic mechanical, thermal and hygric parameters of hardened flue gas desulfurization gypsum are carried out. Moisture diffusivity, water vapor diffusion coefficient, thermal conductivity, volumetric heat capacity and linear thermal expansion coefficient are determined with the primary aim of comparison with data obtained for various types of modified gypsum in the future.

Keywords: flue gas desulfurization (FGD) gypsum, calcined gypsum, mechanical properties, thermal properties, hygric properties.

\section{Introduction}

Calcined gypsum is a historical binder that was used already several thousands of years ago. It has been found in the binder of buildings in the territory of present-day Syria dated 7000 B. C., and it was also used in the Cheops pyramid 2650 B. C. Calcined gypsum is used in many technological modifications, which aim to improve its properties, in particular as a binder of rendering mortars, for the production of stuccowork and also for plasters. In interior applications and in the binder of rendering mortars, calcined gypsum is still employed, due to easy processing and low energy consumption in the production process.

In the second half of the $20^{\text {th }}$ century, technologies were developed for desulfurization of flue gases in power stations and heating plants. These methods are based on the reaction of sulfur(II) oxide formed during combustion of brown coal with a high content of sulfur with limestone $\mathrm{CaCO}_{3}$. Although it seemed that these methods are suitable from the point of view of protection of the environment, there is currently opposition to these technologies. It has been pointed out that the price of desulfurization equipment is too high, and that a large amount of high quality limestone is consumed while a huge amount of flue gas desulfurization (FGD) gypsum is formed as a waste product.

According to the information given in the Mining Yearbook 2000 the amount of sulfur in higher quality brown coal for households ranges from $0.9 \%$ to $1.78 \%$. The coal for energy production contains up to $2.5 \%$ of sulfur. Flue gas desulfurization of one power station block creates up to $20 \mathrm{t}$ of FGD gypsum per hour.

FGD gypsum is produced in great quantities, but is insufficiently used. Calcined gypsum is produced from FGD gypsum in only one power station in the Czech Republic, while the remaining production ends with gypsum that is used only partially as an additive for retarding the setting of cement.

Calcined gypsum is mostly used for the production of gypsum plasterboard. Gypsum, that is not utilized is deposited as waste. Therefore, it is very desirable to pay attention to utilization of calcined gypsum also in those applications where it has not previously been used, i.e. in exteriors. Utilization of binders with minimal energetic demand is in accordance with the current trend in production, when building materials including binders should be produced with a minimized impact on the environment, i.e., with minimal or no production of $\mathrm{CO}_{2}$ and minimal demands on energy. Examples of such binders are belitic cements, binders based on silicate waste products and also calcined gypsum.

Calcined gypsum as a low-energy material can be produced from waste FGD gypsum, by dehydrating it at temperatures between 110 and $150{ }^{\circ} \mathrm{C}$. Then, $\beta$-form of calcined gypsum is formed according to the equation

$\mathrm{CaSO}_{4} \cdot 2 \mathrm{H}_{2} \mathrm{O} \rightarrow \mathrm{CaSO}_{4} \cdot \mathrm{H}_{2} \mathrm{O}+1 \quad \mathrm{H}_{2} \mathrm{O}$.

The solid structure of calcined gypsum is created by reverse hydration when gypsum $\mathrm{CaSO}_{4} \cdot 2 \mathrm{H}_{2} \mathrm{O}$ is again formed. This compound is relatively soluble in water, its solubility being $0.256 \mathrm{mg}$ in $100 \mathrm{~g}$ of water at $20^{\circ} \mathrm{C}$. Therefore, it cannot be utilized in exterior applications, as rain water could dissolve this the product that should safeguard the mechanical properties of the material.

In order to use gypsum elements in exteriors, it is necessary to modify them so that they will exhibit more suitable properties and a longer service life. Modifications of gypsum are usually performed using polymer materials. Bijen and van der Plas [1] reinforced gypsum with E-glass fibers, and modified the binder by using acrylic dispersion in a mixture with melamine. The results show that this material had higher flexural strength and higher toughness than glass fiber reinforced concrete after 28 days. A disadvantage of polymers based on the carbon chain is a decrease in the fire resistance of calcined gypsum elements.

Generally it can be stated that the resistance of hardened gypsum to water has not yet been resolved in a satisfactory way. In the literature, only applications of lime and artificial resins (polyvinylacetate, urea formaldehyde and melamine formaldehyde) have been studied, some inorganic substances such as fluorosilicates, sulfates and silicates were found to increase their surface hardness and impermeability, see Schulze et al. [2].

Therefore, our primary aim is to adjust basic technologies for the production of modified gypsum, particularly from the point of view of hydrophobization and improving its mechanical, hygric and thermal properties. In this paper, we present reference measurements of the mechanical, thermal and hygric properties of common FGD gypsum, which will be 
utilized for a comparison with various types of modified gypsum in the future.

\section{Experimentals methods}

\subsection{Bending strength and compressive strength}

The measurement of bending strength was performed according to the Czech standard ČSN 722301 [3] on $40 \times 40 \times 160 \mathrm{~mm}$ prisms. The specimens were demolded 15 minutes after the final setting time and stored in the testing room. Each specimen was positioned in such a way that the sides that were horizontal during the preparation were in the vertical position during the test. The experiment was performed as a common three-point bending test using a WPM $50 \mathrm{kN}$ device. The distance of the supporting cylinders was $100 \mathrm{~mm}$. The bending strength was calculated according to the standard evaluation procedure. The measurements were done 2 hours, 1 day, 3 days, 7 days, 14 days and 28 days after mixing.

Compressive strength was determined in accordance with the Czech standard ČSN 722301 on the halves of the specimens left over after the bending tests. The specimens were placed between the two plates of the WPM $100 \mathrm{kN}$ device in such a way that their lateral surfaces adjoining during the preparation to the vertical sides of the molds were in contact with the plates. In this way, the imprecision of the geometry on the upper cut off side did not have a negative effect on the experiment. The compressive strength was calculated as the ratio of the ultimate force and the load area.

\subsection{Moisture diffusivity}

\subsubsection{Determination of the apparent moisture diffusivity from a water sorption experiment}

A common water sorption experiment was carried out. The specimen was water and vapor-proof insulated on four lateral surfaces and the face side was immersed $2 \mathrm{~mm}$ in water. A constant water level in the tank was achieved using a bottle placed upside down. The known water flux into the specimen during the suction process was then employed to determine the water absorption coefficient. The samples were tested in constant temperature conditions.

To calculate the apparent moisture diffusivity $D_{w}\left[\mathrm{~m}^{2} \mathrm{~s}^{-1}\right]$, the following approximate relation was employed:

$$
D_{w} \approx\left(\frac{A}{w_{c}}\right)^{2}
$$

where $\mathrm{A}$ is the water absorption coefficient $\left[\mathrm{kgm}^{-2} \mathrm{~s}^{1 / 2}\right]$, and $w_{c}$ is the saturated moisture content $\left[\mathrm{kgm}^{-3}\right]$.

\subsubsection{Determination of moisture diffusivity from moistures profiles}

The capacitance method [4] was employed to measure the moisture content, and the measuring frequency was 250-350 kHz. The parallel electrodes of the capacitance moisture meter had dimensions $20 \times 40 \mathrm{~mm}$.

The moisture profiles were determined using a common capillary suction 1-D experiment in the horizontal position, and the lateral surfaces of the specimens were water and va- por-proof insulated. A moisture meter reading along the specimen was taken every $5 \mathrm{~mm}$. The calibration curve was determined after the last moisture meter reading, when the moisture penetration front was about one half of the length of the specimen, using this last reading and the standard gravimetric method after cutting the specimen into $1 \mathrm{~cm}$ wide pieces. The final calibration curve for the material was constructed from the data of 6 samples. The moisture profiles were then calculated from the calibration curve. The measurements were done at $25^{\circ} \mathrm{C}$ ambient temperature. Moisture diffusivity was determining by the Matano method [5].

\subsection{Water vapor diffusion coefficient}

\subsubsection{Standard cup methods}

In the standard cup methods (dry and wet), the water vapor diffusion coefficient $D$ was calculated from the measured data according to the equation

$$
D=\frac{\Delta m \cdot d \cdot R \cdot T}{S \cdot \tau \cdot M \cdot \Delta p_{p}}
$$

where $D$ is the water vapor diffusion coefficient $\left[\mathrm{m}^{2} \mathrm{~s}^{-1}\right], \Delta m$ the amount of water vapor diffused through the sample $[\mathrm{kg}]$, $d$ the sample thickness [m], $S$ the specimen surface being in contact with the water vapor $\left[\mathrm{m}^{2}\right], \tau$ the period of time corresponding to the transport of mass of water vapor $\Delta m[\mathrm{~s}], \Delta p_{p}$ the difference between the partial water vapor pressure in the air below and above the specimen [Pa], $R$ the universal gas constant $\left[\mathrm{J} \mathrm{mol}^{-1} \mathrm{~K}^{-1}\right], M$ the molar mass of water $\left[\mathrm{kg} \mathrm{mol}^{-1}\right]$, $T$ the absolute temperature $[\mathrm{K}]$.

On the basis of the diffusion coefficient $D$, the water vapor diffusion resistance factor $\mu$ was determined:

$$
\mu=\frac{D_{a}}{D},
$$

where $D_{a}$ is the diffusion coefficient of water vapor in the air $\left[\mathrm{m}^{2} \mathrm{~s}^{-1}\right]$.

In the dry cup method, a sealed cup containing silica gel was placed in a controlled climate chamber with $50 \%$ relative humidity and weighed periodically. For the wet cup method, a sealed cup containing water was placed in an environment with a temperature of about $25^{\circ} \mathrm{C}$ and relative humidity about $50 \%$. The measurements were done at $25^{\circ} \mathrm{C}$ over a period of two weeks.

The steady state values of mass gain or mass loss determined by linear regression for the last five readings were used to determine the water vapor transfer properties.

\subsubsection{Transient method}

In the transient method designed in [6], the measuring device consists of two airtight glass chambers separated by a board-type specimen of the measured material. In the first chamber, a state near to $100 \%$ relative humidity is maintained (achieved with the help of a cup of water), while in the second chamber, there is a state close to $0 \%$ relative humidity (established using some desiccant, in our case a silica gel). Alternately, saturated salt solutions establishing defined relative humidity conditions can be placed in either the wet or the dry chamber, or in both of them. The change in the mass of water in the cup and the mass of the desiccant are recorded by an automatic balance in dependence on time. If steady-state 
measurements are also required, the validity of the condition that the change in the mass of water equals in absolute values the change in the mass of the desiccant is tested, and the experiment continues until this condition is realized. The experiment is carried out under isothermal conditions, as in the case of standard cup methods.

\subsection{Thermal conductivity and volumetric heat capacity}

Thermal properties were measured using ISOMET 2104 (Applied Precision, Ltd., SK). This is a multifunctional instrument for measuring thermal conductivity $\lambda\left[\mathrm{W} \mathrm{m}^{-1} \mathrm{~K}^{-1}\right]$, volumetric heat capacity $C\left[\mathrm{~J} \mathrm{~m}^{-3} \mathrm{~K}^{-1}\right]$ and temperature $\left[{ }^{\circ} \mathrm{C}\right]$ of a wide range of materials. The thermal diffusivity $a\left[\mathrm{~m}^{2} \mathrm{~s}^{-1}\right]$ is calculated by the device from the formula

$$
a=\frac{\lambda}{C} \text {. }
$$

The measurements were done using surface probes with samples, which were placed at laboratory conditions of $25^{\circ} \mathrm{C}$ and about $50 \%$ relative humidity. The relative moisture content by mass of the samples was about $18 \%$.

\subsection{Linear thermal expansion coefficient}

The linear thermal expansion coefficient $\alpha_{T}$ was determined in a common way using the measured length changes (Carl Zeiss optical contact comparator with a precision of $\pm 0.5 \mu \mathrm{m}$ ) between two different temperatures: $25{ }^{\circ} \mathrm{C}$ and $80{ }^{\circ} \mathrm{C}$. It was calculated from the formula

$$
a_{T}=\frac{1}{l_{0, T}} \cdot \frac{\mathrm{d} l}{\mathrm{~d} T},
$$

where $l_{0, T}$ is the length at a reference temperature.

\section{Material and samples}

The material, used for reference measurements was $\beta$-form of calcined gypsum with purity higher than $98 \%$ of FGD gypsum, produced at the electric power station at Počerady, CZ. The water/gypsum ratio was 0.627 . The samples were mixed according to Czech standard ČSN 722301.

For the measurements of particular mechanical, thermal and hygric parameters, we used the following samples: bending strength and compressive strength -8 sets of 3 specimens each $40 \times 40 \times 160 \mathrm{~mm}$, moisture diffusivity - capacitance method -6 specimens $20 \times 40 \times 300 \mathrm{~mm}$, apparent moisture diffusivity -4 specimens $50 \times 50 \times 23-25 \mathrm{~mm}$, water vapor diffusion coefficient - 12 cylinders with the diameter $105 \mathrm{~mm}$ and thickness $10-22 \mathrm{~mm}$, thermal conductivity and volumet- ric heat capacity -6 specimens $70 \times 70 \times 70 \mathrm{~mm}$, linear thermal expansion coefficient -5 specimens $40 \times 40 \times 160 \mathrm{~mm}$.

The samples for determining moisture diffusivity were insulated on all lateral surfaces by water- and vapor-proof plastic foil, the samples for measuring water vapor diffusion coefficient were also water- and vapor-proof insulated on the lateral surfaces by Epoxy resin.

\section{Experimental results}

The basic properties of the studied material for its characterization are shown in Table 1 . In addition to these measurements, which are commonly performed for all porous building materials, we also made a classification of FGD gypsum according to Czech standard ČSN 72 2301. This classification consists in determining the grinding fineness using the 0.2 $\mathrm{mm}$ sieve residue, initial and final setting times using a Vicat device and compressive strength for a period of two hours after mixing. The results are summarized in Table 2. According to these results, FGD gypsum can be classified as G-13 B III.

Table 1: Basic properties of FGD gypsum

\begin{tabular}{|c|c|c|}
\hline $\begin{array}{c}\text { Bulk density } \\
{\left[\mathrm{kgm}^{-3}\right]}\end{array}$ & $\begin{array}{c}\text { Matrix density } \\
{\left[\mathrm{kgm}^{-3}\right]}\end{array}$ & $\begin{array}{c}\text { Open porosity } \\
{[\% \text { by volume }]}\end{array}$ \\
\hline $1019 \pm 1.5 \%$ & $2530 \pm 2.0 \%$ & $60 \pm 3.4 \%$ \\
\hline
\end{tabular}

The dependence of compressive strength and bending strength on time for the first 28 days after mixing is given in Fig. 1. We can see that both strengths decrease slightly for approximately 3 days, but then they begin to increase rapidly and the maximum strengths are achieved after 14 days. These

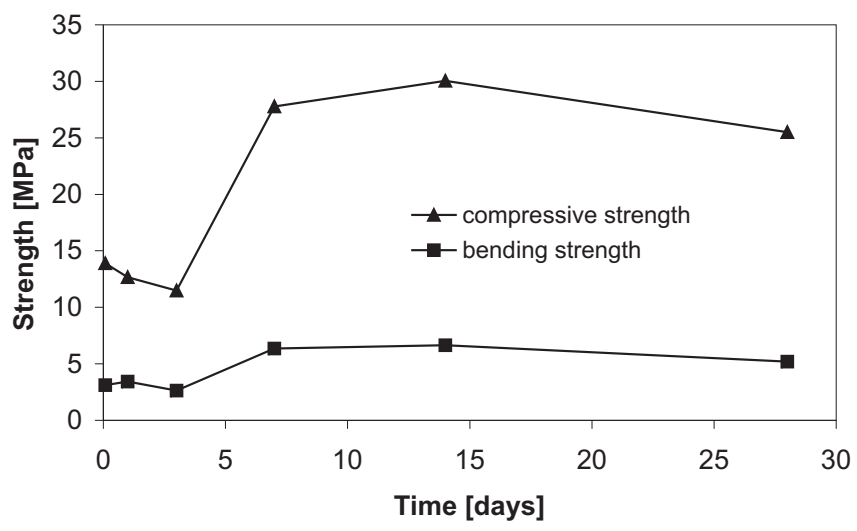

Fig. 1: Compressive strength and bending strength of FGD gypsum

Table 2: Classification of FGD gypsum using ČSN 722301

\begin{tabular}{|l|c|c|c|c|}
\hline & $\begin{array}{c}\text { Compressive strength } \\
{[\mathrm{MPa}]}\end{array}$ & $\begin{array}{c}\text { Initial setting time } \\
{[\mathrm{min}]}\end{array}$ & $\begin{array}{c}\text { Final setting time } \\
{[\mathrm{min}]}\end{array}$ & $\begin{array}{c}0.2 \text { mm sieve residue } \\
{[\%]}\end{array}$ \\
\hline Measured values & 13.3 & 9 & 13 & 1.79 \\
\hline $\begin{array}{l}\text { Limiting values according to } \\
\text { CSN }\end{array}$ & $\begin{array}{c}\text { Minimum } \\
13.0\end{array}$ & $\begin{array}{c}\text { Earliest time } \\
6\end{array}$ & $\begin{array}{c}\text { Latest time } \\
30\end{array}$ & $\begin{array}{c}\text { Maximum } \\
2\end{array}$ \\
\hline Classification according to ČSN & G-13 & & B & III \\
\hline
\end{tabular}




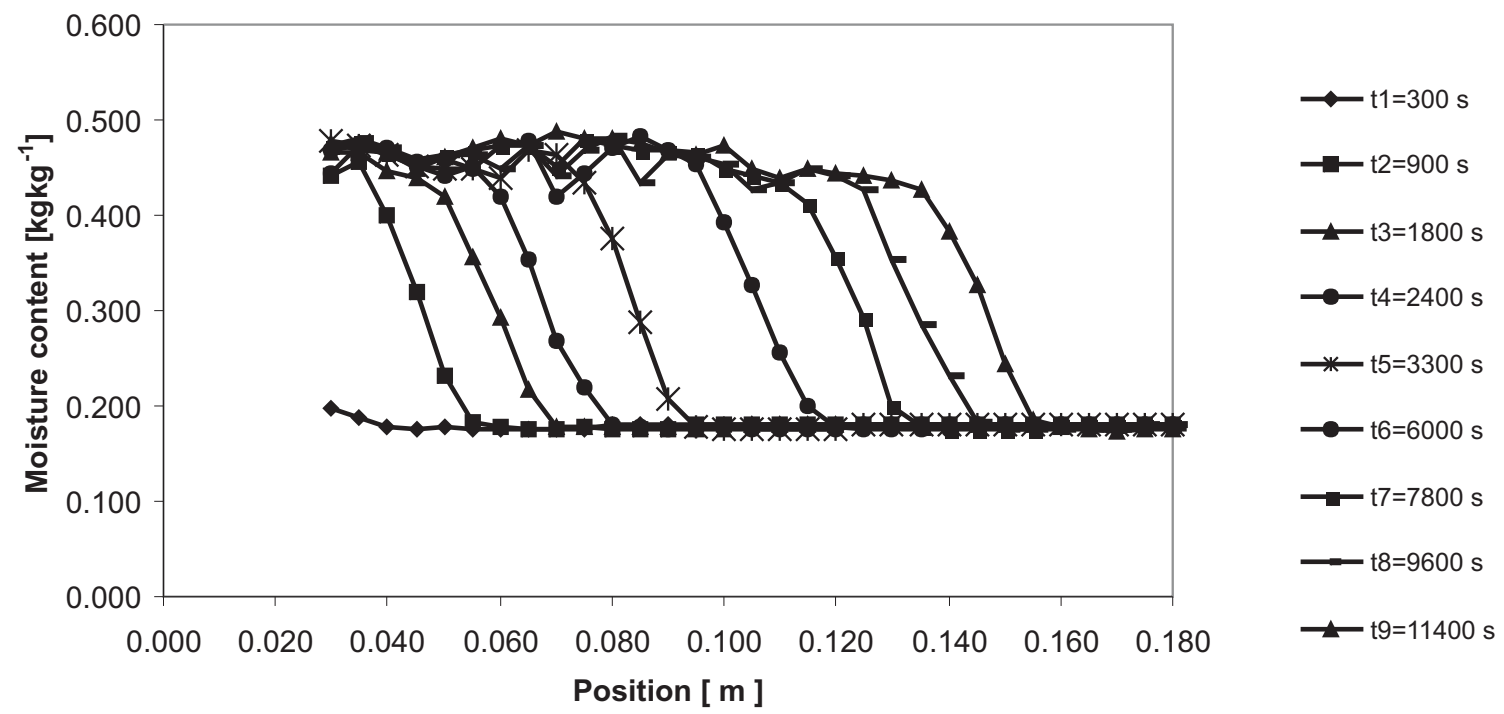

Fig. 2: Typical moisture profiles in FGD gypsum specimens

Table 3: Basic thermal properties of FGD gypsum

\begin{tabular}{|c|c|c|c|}
\hline $\begin{array}{c}\text { Thermal conductivity } \\
{\left[\mathrm{Wm}^{-1} \mathrm{~K}^{-1}\right]}\end{array}$ & $\begin{array}{c}\text { Volumetric heat capacity } \\
{\left[\mathrm{Jm}^{-3} \mathrm{~K}^{-1}\right]}\end{array}$ & $\begin{array}{c}\text { Thermal diffusivity } \\
{\left[\mathrm{m}^{2} \mathrm{~s}^{-1}\right]}\end{array}$ & $\begin{array}{c}\text { Linear thermal expansion coefficient } \\
{\left[\mathrm{K}^{-1}\right]}\end{array}$ \\
\hline $0.47 \pm 10 \%$ & $(1.60 \pm 10 \%) \mathrm{E}+6$ & $(0.29 \pm 10 \%) \mathrm{E}-6$ & $(7.22 \pm 15 \%) \mathrm{E}-6$ \\
\hline
\end{tabular}

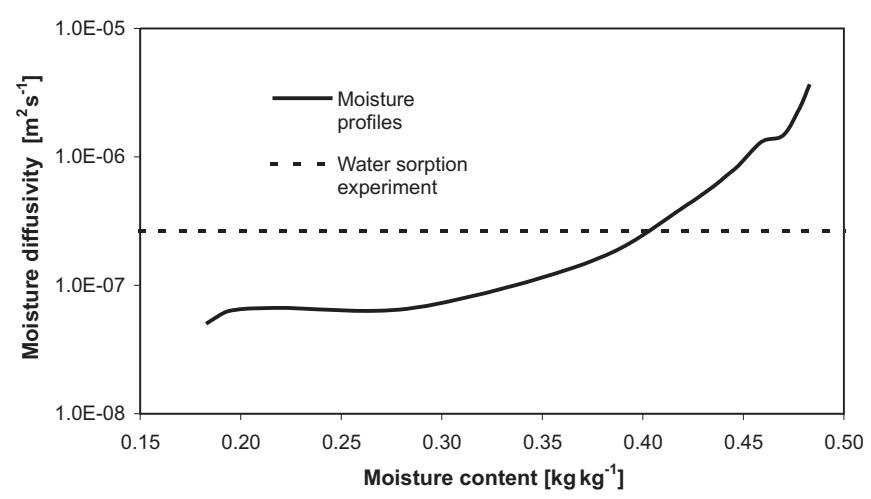

Fig. 3: Moisture diffusivity of FGD gypsum

changes are apparently related to the change of moisture content in the specimens. While the moisture content for the 2-hour specimens was $67 \% \mathrm{~kg} / \mathrm{kg}$, for the 28 -day specimens it was only $24 \%$. So, both compressive strength and bending strength were significantly improved by drying of the specimens.

Table 4 Water vapor diffusion resistance factor

\begin{tabular}{|c|c|c|}
\hline \multicolumn{3}{|c|}{ Water vapor diffusion resistance factor } \\
\hline \multicolumn{2}{|c|}{ Cup methods } & Transient method \\
Dry cup & Wet cup & \\
\hline $17.3 \pm 15 \%$ & $5.44 \pm 15 \%$ & $5.3 \pm 5 \%$ \\
\hline
\end{tabular}

Fig. 2 shows typical moisture profiles determined by the capacitance method. Fig. 3 presents the dependence of moisture diffusivity on the moisture content calculated using the moisture profiles and the apparent moisture diffusivity determined on the basis of the water absorption coefficient. Clearly, the agreement of both measurements is very good, the value of apparent moisture diffusivity being equal to the moisture diffusivity determined from moisture profiles for $83 \%$ of the capillary water saturation value.

Table 3 presents the basic thermal properties of FGD gypsum. Table 4 shows the results of measurements of the water vapor diffusion resistance factor using the dry cup and the wet cup methods and also the transient method. We can see that the results obtained by the transient method are very close to the results of the wet cup method, the difference being within the error range of both methods. This seems to indicate that the boundary condition on the wet side with the relative humidity close to $100 \%$ affected the measurements more significantly than the condition on the dry side.

\section{Discussion}

The possibilities of comparing of the material parameters of FGD gypsum measured in this paper with the parameters determined by other scientists, at least for common gypsum, are very limited. As for FGD gypsum, no data at all were found in common sources.

Among the basic properties, Klein and von Ruffer [7] found porosity of $55 \%$ for gypsum with a water to gypsum ratio of $0.67-0.72$. Mrovec and Perková [8] indicate the bulk density of cast gypsum blocks to be between $840 \mathrm{kgm}^{-3}$ and 
$1130 \mathrm{kgm}^{-3}$. The bulk density of FGD gypsum falls between these limits. According to ČSN 73 0540-3 [9] the bulk density of plasterboard is $750 \mathrm{kgm}^{-3}$.

As for the mechanical properties, Klein and von Ruffer [7] determined compressive strength $20 \mathrm{MPa}$ and the bending strength $4 \mathrm{MPa}$ for $\beta$-gypsum with a water to gypsum ratio of 0.67-0.72. Singh and Garg [10] determined the compressive strength of raw gypsum to be 12-14 MPa in dependence on $\mathrm{pH}$. For gypsum with a water to gypsum ratio of 0.6 , Tazawa [11] measured compressive strength of $18.2 \mathrm{MPa}$, bending strength of 5.59 MPa. We can see that particularly the compressive strength of FGD gypsum is much higher than the mentioned reference data.

For thermal properties, Mehaffey et al. [12] indicate thermal conductivity of gypsum of $0.25 \mathrm{Wm}^{-1} \mathrm{~K}^{-1}$. Sultan [13] gives thermal conductivity of $0.25 \mathrm{Wm}^{-1} \mathrm{~K}^{-1}$ for gypsum in the temperature range of $20-100^{\circ} \mathrm{C}$. Mrovec and Perková [8] indicate thermal conductivity of gypsum as $0.20 \mathrm{Wm}^{-1} \mathrm{~K}^{-1}$. In a comparison with these data, the thermal conductivity of FGD gypsum is about two times higher.

Among the hygric parameters, Hanusch [14] determined the water vapor diffusion resistance factor $m$ in dependence on the thickness of the plasterboard. For a thickness of $9.5 \mathrm{~mm}$ he obtained $\mu=10$ (for 0 and $50 \%$ of relative humidity) and $\mu=6.5$ (for 50 and $100 \%$ of relative humidity), for a thickness of $18 \mathrm{~mm} \mu=8.5$ (for 0 and $50 \%$ of relative humidity) and $\mu=5.5$ (for 50 and $100 \%$ of relative humidity). As we can see, the results of the wet cup measurements with FGD gypsum in this paper correspond reasonably well with the data in [14] but the dry cup data are higher than in [14].

For a detailed and more serious comparison of the data obtained for FGD gypsum in this paper with the results measured by other scientists we unfortunately suffer a lack of more detailed information in the above sources. The authors usually make just references to national standards and requirements that apply to the production and processing of the specimens, and to the testing methods, which are not easily accessible. This complicates a possible comparison. In addition, some of the authors used plasterboard as the studied material, i.e., a gypsum board covered by a paper surface. From the technological point of view, special additives such as setting retarders, additives increasing the fire resistance etc. are used in the production of plasterboard. Therefore, it is an open question whatever we can talk of a common, unmodified gypsum in this case.

As follows from the above considerations, any comparison with reference data can only be approximate. However, even from such a rough comparison it is quite clear that the FGD gypsum analyzed in this paper had significantly higher compressive strength, which is the most important parameter for cast gypsum blocks. This indicates that the overall quality of FGD gypsum was much higher than the gypsum studied in the above reference papers.

\section{Conclusions}

The main aim of the work done in this paper was to obtain a reference data set for unmodified FGD gypsum without any additives. This data set is relatively extensive, including not only mechanical properties but also thermal and hygric prop- erties. These parameters will help in simulating the processes in the material, for instance in contact with water, air humidity, due to changes of temperature, or due to some other load.

It also follows from the results obtained here that the basic material will have to be subjected to substantial modifications primarily due to the worsening of its properties with increasing moisture content. Protection against water and air humidity will have to be provided with the use of hydrophobization additives. Also, some modifications need to be made, aimed at increasing compressive strength and bending strength, for instance using plasticizers, need made. Improvement of thermal properties also seems to be an important topic for the future modifications. However, all these modifications will have to be cross-checked for possible negative effects on other parameters than those intended to be improved.

The modified gypsum that will be developed in future research will be used in the production of cast blocks for application in envelope parts of building structures. Using the measured data it will be possible to simulate both the mechanical and the hygrothermal performance of the designed structure of the envelope and to predict its long-term behavior and service life.

\section{Acknowledgment}

This research has been supported by the Czech Science Foundation, under grant No. 103/03/0006.

\section{References}

[1] Bijen J., van der Plas C.: "Polymer-Modified Glass Fibre Reinforced Gypsum.” Materials and Structures, Vol. 25 (1992), p. 107-114.

[2] Schulze W. et al.: "Necementové malty a betony." SNTL Praha, 1990.

[3] ČSN 722301 Gypsum binding materials, Czech standard (in Czech), Vydavatelství Úřadu pro normalizaci a měření, Praha 1979.

[4] Semerák P., Černý R.: "A Capacitance Method for Measuring the Moisture Content of Building Materials." Stavebni obzor, Vol. 6 (1997), p. 102-103 (in Czech).

[5] Drchalová J., Černý R.: "Non-Steady-State Methods for Determining the Moisture Diffusivity of Porous Materials." Int. Comm. Heat and Mass Transfer, Vol. 25 (1998), p. 109-116.

[6] Černý R., Hošková Š., Toman J.: “A Transient Method for Measuring the Water Vapor Diffusion in Porous Building Materials.” Proc. of International Symposium on Moisture Problems in Building Walls, V. P. de Freitas, V. Abrantes (eds.), Univ. of Porto, Porto, 1995, p. 137-146.

[7] Klein D., von Ruffer C.: "Grundlagen zur Herstellung von Formengips.” Keramische Zeitschrift, Vol. 49 (1997), p. 275-281.

[8] Mrovec J., Perková J.. Pokyny pro projektanty. Technické podklady firmy GYPSTREND (2003).

[9] ČSN 73 0540-3. Tepelná ochrana budov, Část 3: Výpočtové hodnoty veličin pro navrhování a ověřování, s. 15. 
Vydavatelství Úřadu pro normalizaci a měření, Praha, 1994.

[10] Singh M., Garg M.: "Retarding Action of Various Chemicals on Setting and Hardening Characteristics of Gypsum Plaster at Different pH." Cement and Concrete Research, Vol. 27 (1997), p. 947-950.

[11] Tazawa E.: "Effect of Self-Stress on Flexural Strength of Gypsum-Polymer Composites.” Advanced Cement Based Materials, Vol. 7 (1998), p. 1-7.

[12] Mehaffey J. R., Cuerrier P., Carisse G.: “A Model for Predicting Heat Transfer through Gypsum Board/Wood-Stud Walls Exposed to Fire." Fire and Materials, Vol. 18 (1994), p. 297-305.

[13] Sultan M. A.: "Model for Predicting Heat Transfer through Noninsulated Unloaded Steel-Stud Gypsum Board Wall Assemblies Exposed to Fire.” Fire Technology, Vol. 32 (1996), p. 239-259.

[14] Hanusch H.: "Übersicht über Eigenschaften und Anwendung von Gipskartonplatten." Zement-Kalk-Gips, No. 5, (1974), p. 245-251.

\section{Ing. Pavel Tesárek}

phone: +420224355436

e-mail: tesarek@fsv.cvut.cz

Department of Structural Mechanics

RNDr. Jaroslava Drchalová, CSc.

phone: +420224354586

e-mail:drchalov@fsv.cvut.cz

Department of Physics
Czech Technical University in Prague

Faculty of Civil Engineering

Thákurova 7

16629 Praha 6, Czech Republic

Ing. Jiří Kolísko, Ph.D.

phone: +420224353537

e-mail: kolisko@klok.cvut.cz

Czech Technical University in Prague

Klokner Institute

Šolínova 7

16608 Prague 6, Czech Republic

Doc. RNDr. Pavla Rovnaníková, CSc. phone: +420541 147633

e-mail:chrov@fce.vutbr.cz

Institute of Chemistry

University of Technology Brno

Faculty of Civil Engineering

Žižkova 17

66237 Brno, Czech Republic

Prof. Ing. Robert Černý, DrSc.

phone: +420224354429

e-mail: cernyr@fsv.cvut.cz

Department of Structural Mechanics

Czech Technical University in Prague

Faculty of Civil Engineering

Thákurova 7

16629 Praha 6, Czech Republic 